\title{
Profile Analysis of the Scientific Articles Published in the Journal of Morphological Sciences between 2000 and 2017: A Bibliometric Study
}

\author{
Carlos Romualdo Rueff-Barroso ${ }^{1}$ Lorraine Christiny Costa Sepulchro ${ }^{1}$ \\ Fernanda Vieira Botelho Delpupo ${ }^{1}$ Patrícia Breciani Damm ${ }^{1}$ Graziela Gurtler Pomer-Escher ${ }^{1}$ \\ Danielle Resende Camisasca ${ }^{2}$ Valéria Paula Sassoli Fazan ${ }^{3}$
}

1 Department of Morphology, Centro de Ciências da Saúde,
Universidade Federal do Espírito Santo (UFES), Vitória, ES, Brazil
${ }^{2}$ Department of Clinical Dentistry, Centro de Ciências da Saúde,
Universidade Federal do Espírito Santo (UFES), Vitória, ES, Brazil
${ }^{3}$ Department of Surgery and Anatomy, Faculdade de Medicina de Ribeirão
Preto, Universidade de São Paulo (USP), Ribeirão Preto, SP, Brazil

J Morphol Sci 2018;35:255-260.

\begin{abstract}
Address for correspondence Carlos R. Rueff-Barroso, PhD, Master, Departamento de Morfologia, Centro de Ciências da Saúde, Universidade Federal do Espírito Santo (UFES), Av. Marechal Campos, 1468, Maruípe, CEP: 29.043-900, Vitória, ES, Brazil (e-mail: carlosrueff@yahoo.com.br).
\end{abstract}

\begin{abstract}
Keywords

- bibliometry

- bibliometric study

- scientific production

- research subject

- journal of morphological sciences

Introduction The Journal of Morphological Sciences (JMS), the official journal of the Brazilian Society of Anatomy, is an interesting option for researchers to publish in the field of morphology. It includes articles that cover a wide variety of topics, such as gross and microscopic human and animal anatomy, embryology, cell and molecular biology, clinical cases and reviews. We aimed to perform a bibliometric study to analyze the profile of JMS publications from 2000 to 2017, in order to understand in depth the origins of the researches and the subject of the manuscripts published in this journal. Material and Methods This is a descriptive bibliographical review research, with a bibliometric analysis of the scientific production of the JMS between 2000 and 2017. A total of 894 publications were analyzed, and they were distributed in 63 issues and organized into 18 volumes. Three groups of information were considered: a) "identification of the published articles;" b) "origin and authorship of the published articles;" and c) "research subject in the published articles."

Results Most of the published manuscripts were original articles (72.5\%) and their subjects were mainly microscopic animal anatomy (27\%) and gross human anatomy (26.6\%). A total $63.3 \%$ of the manuscripts involved at least one Brazilian institution, and $59.4 \%$ of those were public institutions.

Conclusion This manuscript provides an important contribution to those who are publishing in the JMS, since the authors can find a great deal of information on the quality of the science that is being published in the journal, as well as demographic information on authors and institutions.
\end{abstract}

\section{Introduction}

In the context of the evolution of world scientific production, Brazil has been standing out since 1996 among the countries that are considered scientifically emerging, with an expo- nentially increasing number in the production of scientific articles. ${ }^{1}$ Anatomy has been one of the most prominent scientific areas of research in Brazil since the 1950s.

The Brazilian Society of Anatomy (BSA) history has its official beginning on July $31^{\text {st }}, 1952$, during the 1 st Meeting received

October 18, 2018

accepted

November 8, 2018
DOI https://doi.org/

10.1055/s-0038-1676541. ISSN 2177-0298.
Copyright $(2018$ by Thieme Revinter

Publicações Ltda, Rio de Janeiro, Brazil
License terms

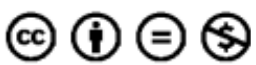


of Brazilian Anatomy, which occurred in the Department of Descriptive and Topography Anatomy of the School of Medicine of Universidade de São Paulo (USP, in the Portuguese acronym), presided by Professor Álvaro Fróes da Fonseca. At the end of the meeting, Professor Renato Locchi proposed the foundation of the BSA and he was chosen to be the first President of the BSA (1952-1953). ${ }^{2}$

Medical and biological societies usually have instruments to promote the progress of science in specific areas. Among these instruments are the organization of scientific meetings (congresses, workshops, symposiums, courses) and the creation of scientific journals. The BSA, seeking to congregate its members and contribute to the development of the morphological sciences, created in 1984 the Revista Brasileira de Ciências Morfológicas (Brazilian Journal of Morphological Sciences).

In order to improve the quality of the submitted articles and publish scientific articles by researchers from different parts of the world, in 1995 the journal had its name changed to Brazilian Journal of Morphological Sciences, and later on, in 2010, after a new name change, it became known as Journal of Morphological Sciences (JMS). Currently, it is the official scientific journal of the BSA and of the Pan American Association of Anatomy. Since 2010, the articles published in the JMS are available for free on the website of the journal, improving and increasing the access to published scientific research and knowledge diffusion regarding the morphological sciences.

Currently, the JMS has indexed databases such as the Latin-American and Caribbean Literature on Health Sciences (LILACS, in the Portuguese acronym), the Latin American Index Medicus (IMLA, in the Portuguese acronym), the Veterinary Science Database of the Centre for Agriculture and Bioscience International (CABI), the CAB Abstracts, the $\mathrm{CAB}$ Health, the Biological Abstracts and Zoological Record (BioSciences Information Service of Biological Abstracts, BIOSIS) and Scopus. In 2018,the JMS established an important partnership with Thieme Medical Publishers, and continued to work on indexation in the Scientific Electronic Library Online (SCIELO) and later in PubMed through the National Center for Biotechnology Information (NCBI).

The Coordination for the Improvement of Higher Education Personnel (CAPES, in the Portuguese acronym) - a Brazilian federal foundation that regulates the graduate (masters and PhD degrees) programs in Brazil, defines criteria for scientific journals that are called Qualis. Qualis is the set of procedures used by CAPES to stratify the quality of the intellectual output of graduate programs in different fields of science. This stratification has the following grades: A1, A2, B1 to B5 and C. The JMS is currently qualified as B2 in agrarian sciences, B3 in physical education, interdisciplinary, nutrition, dentistry, psychology and zootechnic/fisherie resources, B4 in biodiversity, biotechnology, pharmacy and medicine I and II, and B5 in biological sciences I and II, teaching and veterinary medicine. ${ }^{3}$

The JMS has expanded the number of anatomical subjects it covers, including gross anatomy and microscopy for both human and animal models, making the journal an interesting option for researchers in many fields to publish their work. In addition, the JMS began a new modernization project aiming to advance and achieve higher indexes of editorial quality and scientific standards in the international scenario. Therefore, the aim of the present study was to perform a bibliometric analysis of the profile of the JMS publications from 2000 to 2017, in order to understand in depth the research origin and subject of the manuscripts published in the journal.

\section{Materials and Methods}

\section{Study Design and Setting}

The present research is a descriptive bibliographical review, with a bibliometric analysis of the scientific production of the JMS between 2000 and 2017. A total of 894 publications were analyzed, and they were distributed in 63 issues and organized into 18 volumes. In the present study, three groups of information were considered: a) "identification of the published articles;" b) "origin and authorship of the published articles;" and c) "research subject in the published articles." The following items were analyzed for each group:

a) Identification of the published articles: descriptive analysis of the number of evaluated and published articles and descriptive analysis of the types and anatomical areas of the articles.

b) Origin and authorship of the published articles: descriptive analysis of the variables related to the number and nationality of the institutions involved in the publications, the administrative nature (public or private) of the institutions, the institutions and departments that had the main role in the publications. In this group, a descriptive analysis of the demographic variables related to the first authors of the published articles was made as well, highlighting the region of Brazil of the Brazilian authors, the distribution of the Brazilian authors that most published by region, and the countries of the first foreign authors.

c) Research subject in the published articles: descriptive analysis of the terms of anatomical structures in humans and animals present in the article titles, abstracts and keywords, the main anatomical variations in humans and animals, the main animal models used, the main anatomical structures studied in humans and animals, and an analysis of research funding.

\section{Sample}

We analyzed the full articles published in the JMS (from 2000 to 2017) that were available on the journal website (http:// www.jms.org.br/) during the time set for the investigation. The manuscripts were divided into different anatomy subjects ( - Table 1) according to the keywords and description of the methods. Data collection was performed by six independent blinded researchers, and re-analyzed four times by the entire research team.

\section{Inclusion and Exclusion Criteria}

Original articles, reviews or mini-reviews, case reports and brief communications were considered in the present study ( - Table 1). The exclusion criteria were: articles that appeared 
Table 1 Article type and subject descriptive analysis of the manuscripts published in the Journal of Morphological Sciences between 2000 and 2017

\begin{tabular}{|c|c|}
\hline Article type and subject & Total n (\%) \\
\hline \multicolumn{2}{|l|}{ Types of articles } \\
\hline Original article & $469(72.5)$ \\
\hline Review article/mini-review & $91(14.1)$ \\
\hline Case report & 77 (11.9) \\
\hline Short communication & $10(1.5)$ \\
\hline Total & $647(100)$ \\
\hline \multicolumn{2}{|l|}{ Anatomic subject distribution } \\
\hline Microscopic animal anatomy & $175(27.0)$ \\
\hline Gross human anatomy & $172(26.6)$ \\
\hline Two or more subjects & $147(22.7)$ \\
\hline Gross animal anatomy & $52(8.0)$ \\
\hline Cell biology and embryology & $23(3.6)$ \\
\hline Clinical anatomy & $20(3.1)$ \\
\hline Microscopic human anatomy & $16(2.5)$ \\
\hline Compared anatomy & $12(1.9)$ \\
\hline Morphological techniques & $9(1.4)$ \\
\hline Education in morphology & $7(1.1)$ \\
\hline Applied morphology & $6(0.9)$ \\
\hline Morphology and arts & $4(0.6)$ \\
\hline Pathology & $3(0.4)$ \\
\hline Anthropology & $1(0.2)$ \\
\hline $\begin{array}{l}\text { History and morphological } \\
\text { sciences }\end{array}$ & $0(0.0)$ \\
\hline Total & $647(100)$ \\
\hline
\end{tabular}

in the list of volumes and/or issues of the journal, but were not available for download in full in the website, duplicate articles, articles whose PDF file did not correspond to the referred article, retracted articles, and retraction notices.

\section{Data Analysis}

Data organization was performed using Microsoft Excel (Microsoft Corporation, Redmond WA, US) spreadsheets. When applicable, the data analyses were performed using the GraphPad Prism (GraphPad Software, Inc., La Jolla, CA, US) software, version 7, and demonstrated through descriptive analysis in tables and graphs. The data are presented in absolute and relative values ( $\mathrm{n}[\%])$.

\section{Results}

A total of 894 manuscripts were published in the JMS between 2000 and 2017. - Table 1 indicates that, from a total of 647 manuscripts included in the study, most of the published manuscripts were original articles (72.5\%) while short communications comprised only $1.5 \%$ of the total. - Table 1 also shows the anatomic subjects of the manuscripts, and indicates that most of them were about microscopic animal anatomy (27\%) and gross human anatomy (26.6\%).

-Table 2 indicates the institutions and departments involved in the publications. A total of 323 different institutions were identified and the most cited one was Universidade de São Paulo (9.2\%), but in 201 manuscripts, the department was not indicated. When the department was indicated, $27.1 \%$ referred to a department of anatomy. Most of the manuscripts indicated a single institution involved in the publication (56\%). A total of 410 (63.3\%) manuscripts involved at least one Brazilian institution, and $59.4 \%$ of them were public institutions.

- Table 3 shows demographic data from the first authors of the manuscripts. A total of 422 articles had a Brazilian first author, and most of these manuscripts (303/71.8\%) originated from the Southeastern region of Brazil, and the state of São Paulo was the most cited one (224/73.9\%). Most authors from abroad were from India (80/35.6\%).

Specific information about the research subjects in the published articles are shown in -Table 4. The subjects were separated according to the anatomical terms most present in the titles, abstracts or keywords in each manuscript. Studies involving human anatomy and animal anatomy were represented separately.

In total, there were 183 studies on anatomical variations in humans, and the median nerve was the most described structure (4.4\%), followed by the brachial artery (2.7\%). As for the studies on anatomical variations in animals, there were only 15 in total, and the most described structure was the atrioventricular valves (26.7\%), followed by the liver (13.3\%). In total, there were 331 studies using animal models, and the most common animals used were rats (99/29.9\%), followed by bees (34/10.3\%).

-Fig. 1 shows the organs or the anatomical structures most studied in human and animal models. For humans, the most commonly investigated structure was the skull, while for animals it was the testis.

Among the 647 articles analyzed, 182 (28.1\%) were funded by one or more funding agencies, and 465 (71.9\%) were unfinanced research.

\section{Discussion}

The present article is the first bibliometric study about the JMS. It includes a large amount of information on authors, manuscript subjects and investigated morphological structures published in the journal since it became available on line. Bibliometric studies are widely used in the field of information science, and enable researchers to make quantitative analyses of the academic literature. ${ }^{4}$ They are a promising methodology of investigation because they reveal distributions and tendencies in specific research fields. For the JMS, this bibliometric study indicated the characteristics of the research subjects and its authors, which might influence or guide research groups seeking a morphological journal to publish their results. 
Table 2 Institutions and departments involved in the manuscripts published in the Journal of Morphological Sciences between 2000 and 2017

\begin{tabular}{|c|c|}
\hline Institutions and departments & Total n (\%) \\
\hline \multicolumn{2}{|l|}{ Number of institutions in each manuscript } \\
\hline One & $363(56.0)$ \\
\hline Two & $190(29.4)$ \\
\hline Three or four & $89(13.8)$ \\
\hline Five and more & $5(0.8)$ \\
\hline \multicolumn{2}{|l|}{ Nationality of the institutions } \\
\hline Brazilian & $410(63.3)$ \\
\hline Foreign & $223(34.5)$ \\
\hline Both (co-authorships) & $14(2.2)$ \\
\hline \multicolumn{2}{|l|}{ Administrative nature of the institutions } \\
\hline Public & $192(59.4)$ \\
\hline Private & $115(35.6)$ \\
\hline Not identified & $16(5.0)$ \\
\hline \multicolumn{2}{|l|}{$\begin{array}{l}\text { Most cited institutions participating in the } \\
\text { manuscripts }\end{array}$} \\
\hline Universidade de São Paulo & $95(9.2)$ \\
\hline Universidade Estadual de Campinas & $60(5.8)$ \\
\hline Universidade Estadual Paulista & $56(5.4)$ \\
\hline Universidade São Judas Tadeu & $48(4.6)$ \\
\hline Universidade Federal de Pernambuco & $25(2.4)$ \\
\hline Manipal Academy of Higher Education & $25(2.4)$ \\
\hline Universidade Federal de São Paulo & $22(2.1)$ \\
\hline Universidade Federal do Rio Grande do Sul & $21(2.0)$ \\
\hline Universidade Federal de Uberlândia & $17(1.6)$ \\
\hline University of Nairobi & $17(1.6)$ \\
\hline Other institutions & $649(62.9)$ \\
\hline \multicolumn{2}{|l|}{$\begin{array}{l}\text { Most cited departments participating in the } \\
\text { manuscripts }\end{array}$} \\
\hline Department of Anatomy & $259(27.1)$ \\
\hline Department of Morphology & $115(12.0)$ \\
\hline Department of Biological Sciences & $84(8.8)$ \\
\hline Department of Cell Biology & $36(3.8)$ \\
\hline Department of Pathology & $31(3.2)$ \\
\hline Department of Physical Therapy & $24(2.5)$ \\
\hline Department of Histology & $18(1.9)$ \\
\hline Department of Surgery & 18 (1.9) \\
\hline Department of Veterinary Anatomy & $17(1.8)$ \\
\hline Department of Physical Education & $16(1.7)$ \\
\hline Other departments & $337(35.3)$ \\
\hline
\end{tabular}

The JMS published original articles, reviews, case reports and short communications on several fields of anatomy and morphology, as demonstrated in - Table 1. This wide variety of options of anatomical fields provides researchers with
Table 3 Demographic origin (by country and Brazilian region) of the authors of the manuscripts published in the Journal of Morphological Sciences between 2000 and 2017

\begin{tabular}{|l|l|}
\hline Demographic data & Total $\mathbf{n}(\%)$ \\
\hline Brazilian region of origin of first authors & \\
\hline Southeastern & $303(71.8)$ \\
\hline Southern & $50(11.8)$ \\
\hline Northeastern & $46(10.9)$ \\
\hline Midwestern & $20(4.7)$ \\
\hline Northern & $2(0.5)$ \\
\hline Not identified & $1(0.3)$ \\
\hline Total & $422(100)$ \\
\hline $\begin{array}{l}\text { Native states of the first authors from the } \\
\text { Brazilian Southeast }\end{array}$ \\
\hline São Paulo & \\
\hline Minas Gerais & $224(73.9)$ \\
\hline Rio de Janeiro & $42(13.9)$ \\
\hline Espírito Santo & $26(8.6)$ \\
\hline Total & $11(3.6)$ \\
\hline Country of first author (other than Brazil) & $303(100)$ \\
\hline India & $80(35.6)$ \\
\hline Nigeria & $33(14.7)$ \\
\hline Kenya & $17(7.6)$ \\
\hline Portugal & $8(3.6)$ \\
\hline United States of America & $7(3.1)$ \\
\hline Iran & $6(2.7)$ \\
\hline Malaysia & $6(2.7)$ \\
\hline Argentina & $5(2.2)$ \\
\hline Egypt & $5(2.2)$ \\
\hline Spain & $5(2.2)$ \\
\hline Others countries & $225(100)$ \\
\hline Total & \\
\hline
\end{tabular}

many possibilities of subjects to investigate, write, and publish.

Most of the articles published in the JMS are original articles, following a prerogative of quality and requirement of scientific journals, such as those that are part of the SCIELO Brazil collection. ${ }^{5}$ We also observed that most of the publications were about microscopic animal anatomy, followed closely by studies on macroscopic human anatomy. Microscopic studies in animal models form the basis of morphological studies in all areas of health and veterinary sciences, making the journal an important alternative for the publication of this type of study with an experimental design. ${ }^{6}$

According to Aversi-Ferreira et $\mathrm{al}^{7}$ the dissection of cadavers is an important tool in the study of anatomy, as it is a teaching methodology that encourages critical and investigative thinking, integrating basic education with clinical knowledge. The JMS has an expressive number of 
JMS Bibliometric Study Rueff-Barroso et al. 259

Table 4 Descriptive analysis of the research subjects in the manuscripts published in the Journal of Morphological Sciences between 2000 and 2017

\begin{tabular}{|l|l|l|l|l|l|l|}
\hline Variables & $\begin{array}{l}\text { Terms in the } \\
\text { title }\end{array}$ & $\mathbf{n}(\%)$ & Terms in the abstract & $\mathbf{n}(\%)$ & $\begin{array}{l}\text { Terms in the } \\
\text { keywords }\end{array}$ & $\mathbf{n}(\%)$ \\
\hline \multirow{2}{*}{$\begin{array}{l}\text { Anatomical } \\
\text { structures } \\
\text { in humans }\end{array}$} & Skull, skull base & $14(4.3)$ & Skull, skull base, cranium & $29(2.1)$ & Median nerve & $9(1.4)$ \\
\cline { 2 - 7 } & Median nerve & $8(2.4)$ & Upper limb & $17(1.2)$ & Brachial plexus & $7(1.1)$ \\
\cline { 2 - 7 } & Liver & $5(1.5)$ & Forearm & $16(1.2)$ & Heart & $6(0.9)$ \\
\cline { 2 - 7 } & Other terms & $301(91.8)$ & Other terms & $1319(95.5)$ & Other terms & $616(96.6)$ \\
\cline { 2 - 7 } & Total & $328(100)$ & Total & $1381(100)$ & Total & $638(100)$ \\
\hline \multirow{4}{*}{$\begin{array}{l}\text { Anatomical } \\
\text { structures } \\
\text { in animals }\end{array}$} & Liver & $10(4.3)$ & Testis, testicle & $22(2.2)$ & Skeletal muscle & $9(2.8)$ \\
\cline { 2 - 7 } & Testis, testicle & $9(3.8)$ & Brain, cerebrum & $18(1.8)$ & Testis, testicles & $8(2.5)$ \\
\cline { 2 - 7 } & Skeletal muscle & $8(3.4)$ & Ovary & $954(94.3)$ & $\begin{array}{l}\text { Other } \\
\text { structures }\end{array}$ & 295 (92.8) \\
\cline { 2 - 7 } & $\begin{array}{l}\text { Other } \\
\text { structures }\end{array}$ & $207(88.5)$ & Other structures & $1011(100)$ & Total \\
\cline { 2 - 7 } & Total & $234(100)$ & Total & $318(100)$ \\
\hline
\end{tabular}

Notes: The subjects were separated according to the anatomical terms most present in the titles, abstracts or keywords in each manuscript. Terms used in plural were also considered for this analysis.

cadaveric studies, being the second most published type of study in the journal, either as original articles or case reports in which anatomical variations are described. Thus, the JMS is also an important source of information for clinicians to better understand possible variations that course with clinical manifestations.

Although co-authoring between different institutions may be an important tool to promote the exchange of diverse and complementary knowledge, which is essential for the development of innovations, ${ }^{8}$ most of the manuscripts published in the JMS were written by authors from the same institution. Nevertheless, studies show that the increase in co-authorship among researchers from one institution tends to be interpreted positively, ${ }^{8}$ because the greater interaction among researchers contributes to increase the quality of the produced articles. 9,10

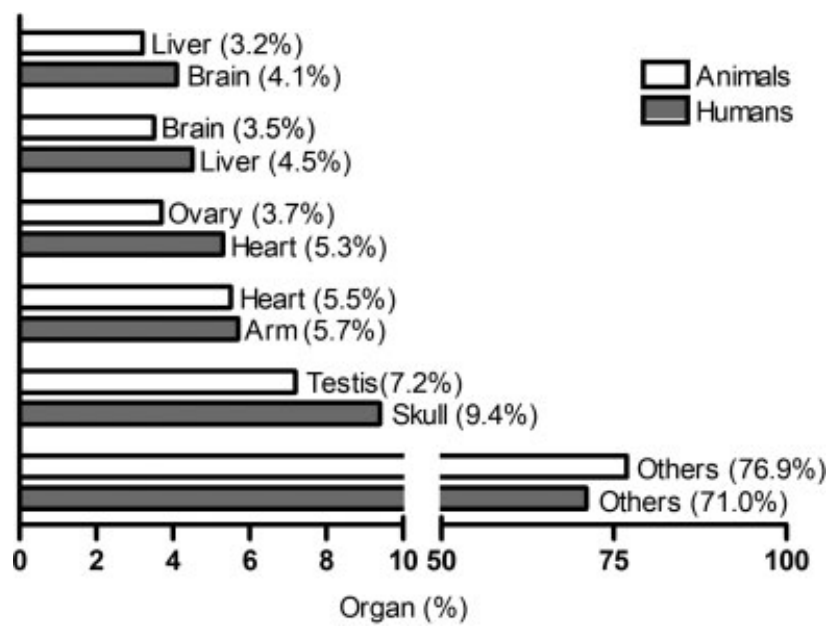

Fig. 1 Descriptive analysis of the most studied organs in humans and animals in the manuscripts published in the Journal of Morphological Sciences between 2000 and 2017.
Our study shows that despite the international contribution in the JMS, the number of Brazilian publications is notably higher (63.3\%), and they come mainly from the Southeastern region, especially from the state of São Paulo. Poletto and Faraco Junior ${ }^{11}$ explain that the differences in the number of publications among Brazilian states are mainly due to the disparity between these states in the number of graduate programs (masters and $\mathrm{PhD}$ ), which is associated with the amount of financial resources distributed by the various scientific research supporting agencies. São Paulo is the richest Brazilian state, with a gross domestic product (GDP) per capita of R $\$ 33,624.00$ (in terms of GDP per capita, it only comes second after the Federal District of Brasília, which is not a state, but the country's capital). It is also one of the richest states in Latin America, with a GDP per capita surpassing that of countries like Argentina, Paraguay, Uruguay, and Bolivia. ${ }^{12}$ The Brazilian Universities that most published in the JMS were USP, Universidade Estadual de Campinas (Unicamp, in the Portuguese acronym), Universidade Estadual Paulista (Unesp, in the Portuguese acronym) and Universidade São Judas Tadeu, all from São Paulo; the first three in this list are public institutions. Some factors may be directly related to these data. Firstly, public universities have more funds for the development of scientific research, compared with private universities. ${ }^{13}$ Secondly, the state of São Paulo has a very significant history within Brazilian anatomy, and to this day the headquarters of the Brazilian Society of Anatomy are in the capital city of the state, which is also called São Paulo. ${ }^{14}$ Thirdly, USP not only appears as the largest Brazilian institution to publish in the JMS, but it is also the university with the highest number of publications among Brazilian universities in the world. ${ }^{15}$ This demonstrates the prestige of the JMS among the Brazilian morphologists, and it indicates that the journal is an important option for the publication of high quality research in morphology. 
Considering the nationality of the institutions involved as well, the foreign ones were responsible for $34.5 \%$ of the independent publications, and participated in $2.2 \%$ of the publications in partnership with Brazilian institutions. Most of the international articles published in the JMS are from India. This is in line with studies that show that since the year 2000 India has been experiencing an exponential growth in scientific production. ${ }^{16}$ A Thomson Reuters study predicted that between 2015 and 2020 India's research productivity growth could already outpace that if the socalled G8 countries. ${ }^{17}$ India's interest in Brazilian scientific literature has also been confirmed by CAPES data, which showed that India and the US are the countries that most access scientific articles in Brazil. ${ }^{18}$

When we analyzed all of the research institutions that published in the JMS, we observed that almost $60 \%$ of them are public. Studies show that despite the difficulty in receiving resources for administrative management in public universities, they still offer more resources for research when compared with private universities. ${ }^{13}$

The year 2018 marks the beginning of a major change for the JMS; with its association with Thieme Medical Publishers, the magazine took on a more modern look. As one of the journals represented and coordinated by Thieme, the JMS gains more relevance in the field of anatomy, and this opens the way for a substantial improvement in its indexes, with the addition of the experience of Thieme and a greater dissemination in the international scenario.

\section{Conclusion}

The JMS is a dynamic and versatile journal that covers a wide variety of areas of interest that has the possibility of increasing the number of researches submitted for editorial review and subsequent publication. It has specialists in several areas, from macroscopy to microscopy, who publish and also review articles. It is an international journal, recognized by major Brazilian and foreign universities, and has sought to improve its qualification to achieve new indexations and improve its concept with the Capes.

The present manuscript provides an important contribution to those who are publishing in the JMS, since authors can find much information on the quality of the science that is being published in the journal, as well as demographic information on authors and institutions.

Conflicts of Interest

The authors have none to declare.

\section{References}

1 Sidone OJG, Haddad EA, Mena-Chalco JP. A ciência nas regiões brasileiras: evolução da produção e das redes de colaboração científica. Transinfo 2016;28(01):15-31

2 Sociedade Brasileira de Anatomia. Available at: http://sbanatomia. org.br/historia/

3 Ministério da Educação. Coordenação de Aperfeiçoamento de Pessoal de Nível Superior. Available at: http://capes.gov.br/. Accessed October 15, 2018

4 Bellis ND. Bibliometrics and Citation Analysis: From the Science Citation Index to Cybermetrics. Lanham, Md: Scarecrow Press; 2009:415

5 Scientific Electronic Library Online. Critérios, política e procedimentos para a admissão e a permanência de periódicos científicos na coleção Scielo Brasil. 2017. Available at: http://www.scielo.br/ avalia-cao/20141003NovosCriterios_SciELO_Brasil.pdf. Accessed August 30, 2018

6 Hackam DG. Translating animal research into clinical benefit. BMJ 2007;334(7586):163-164

7 Aversi-Ferreira TA, Nascimento GNL, Vera I, Lucchese R. The practice of dissection as teaching methodology in anatomy applied to medical education. Int J Morphol 2010;28(01):265-272

8 Gazda E, Quandt CO. Colaboração interinstitucional em pesquisa no Brasil: tendências em artigos na área de gestão da inovação. RAE Eletrônica 2010;9(02):1-27

9 Bertero CO, Vasconcelos FC, Binder MP. Estratégia empresarial: a produção científica brasileira entre 1991 e 2002. Rev Adm Emp 2003;43(04):48-63

10 Rodrigues SB, Carrieri AP. A tradição anglo-saxônica nos estudos organizacionais brasileiros. Rev Adm Contemp 2001;5:81-102

11 Poletto VC, Faraco Junior IM. Bibliometric study of articles published in a Brazilian journal of pediatric dentistry. Braz Oral Res 2010;24(01):83-88

12 World Atlas. The richest and poorest states of Brazil. Available at: https://www.worldatlas.com/articles/the-richest-and-pooreststates-of-brazil.html. Accessed October 15, 2018

13 Ministério da Educação. Coordenação de Aperfeiçoamento de Pessoal de Nivel Superior. Research in Brazil. Available at: http://capes. gov.br/images/stories/download/-diversos/17012018-CAPES-InCitesReport-Final.pdf. Accessed August 30, 2018

14 Talamoni ACB, Bertolli Filho C. A anatomia e o ensino de anatomia no Brasil: a escola boveriana. Hist Cienc Saude Manguinhos 2014; 21(04):1301-1322

15 QS World University Rankings. Available at: https://www.topuniversities.com/university-rankings/world-university-rankings/ 2018. Accessed October 15, 2018

16 Sandhu A. Advancing science in India. Sience. 2013. Available at: http://www.sciencemag.org/features/2013/02/advancing-scienceindia. Accessed October 15, 2018

17 Adams J, King C, Singh V. Global research report: India. Thomson Reuters; 2009. Available at: http://ips.clarivate.com/m/pdfs/grrIndia-oct09_ag0908174.pdf. Accessed October 15, 2018

18 Governo Federal. EUA e Índia são os que mais acessam artigos científicos brasileiros. Available at: http://www.brasil.gov.br/governo/2010/07/eua-e-india-sao-os-que-mais-acessam-artigos-cientificos-brasileiros. Accessed October 30, 2018 